\title{
"As by a New Pentecost": Embodied Prayer in Catholic Charismatic Renewal Following Vatican II
}

\author{
Michelle Blohm
}

Citation: Blohm, Michelle. 2021. “As by a New Pentecost": Embodied Prayer in Catholic Charismatic Renewal Following Vatican II. Religions 12: 591. https://doi.org/ $10.3390 /$ rel12080591

Academic Editor: Salvador Ryan

Received: 3 June 2021

Accepted: 27 July 2021

Published: 31 July 2021

Publisher's Note: MDPI stays neutral with regard to jurisdictional claims in published maps and institutional affiliations.

Copyright: (C) 2021 by the author. Licensee MDPI, Basel, Switzerland. This article is an open access article distributed under the terms and conditions of the Creative Commons Attribution (CC BY) license (https:/ / creativecommons.org/licenses/by/ $4.0 /)$.
Duquesne University, Pittsburgh, PA 15282, USA; mblohm535@gmail.com

\begin{abstract}
On 25 December 1961, John XXIII convoked the Second Vatican Council with his apostolic constitution Humanae salutis, praying that God would show again the wonders of the newborn Church in Jerusalem "as by a new Pentecost". Not six years later, in 1967, a group of students at Duquesne University in the United States prayed while on retreat for an infusion of the Holy Spirit that they might also experience the power of Pentecost. They received what they reported to be the gifts of the Holy Spirit, and out of the spiritual experiences of that retreat arose what would become an international movement known as the Catholic Charismatic Renewal. This movement, influenced by Pentecostalism, would develop its own embodied praxis of prayer that seeks a renewed encounter with the power of the Holy Spirit made manifest at Pentecost. This article analyzes the embodied prayer language of the Renewal by drawing from Louis-Marie Chauvet's distinction between language as mediation (or, symbol) and language as tool (or, sign). It will use Chauvet's distinction as a hermeneutic to flesh out the relationship between post-Vatican II charismatic prayer practices and their intended purpose of participating in the encounter of Pentecost.
\end{abstract}

Keywords: Catholic Pentecostalism; Vatican II; Suenens; Léon-Joseph; Chauvet; Louis-Marie; prayer

\section{Introduction}

One of the most distinctive spiritual movements arising in the wake of the Second Vatican Council is the Catholic Charismatic Renewal, the formal name given to Catholic Pentecostalism. Though the Renewal is profoundly influenced in its historical origins by Protestant Pentecostalism, its interpreters regard the Renewal as a true outgrowth of Vatican II. "Pentecostalism" in general is typically defined according to its historical genealogy as a spiritual movement arising in the United States in the Twentieth Century (Synan 1997). Nevertheless, it is its hermeneutic genealogy, the origins and history of its self-interpretation, that markedly distinguishes Catholic Pentecostalism from other forms of Pentecostalism. "Pentecostalism" in general is characterized by embodied prayer experiences that are believed to connect worshippers to an encounter with the graces poured out upon the early New Testament Church at Pentecost. Catholic Pentecostalism interprets these graces to bring newness to the post-Vatican II Church in a new age. Francis Sullivan, who participated in Vatican II as an advisor on the charisms for the Constitution On the Church, Lumen gentium, argues that what Vatican II accomplishes on the theoretical level in renewing charisms in the Church, the Catholic Charismatic Renewal accomplishes as an experience of prayer (Sullivan 1982, p. 79). Joseph Bagiackas even goes so far as to refer to the Renewal's consequence as "a manifestation of the power of God for the implementation of the Second Vatican Council" (Bagiackas 1983, p. 16).

Due to the interplay of historical and hermeneutic factors defining the Catholic Charismatic Renewal, both of these factors also must be examined when investigating the significance of embodied prayer phenomena encountered in the context of the Renewal. Here, I first argue that the Renewal is characterized by a desire to experience in prayer the wonders and the power of the Holy Spirit at Pentecost in the Church and is interpreted as a divine response to John XXIII's prayer for the Council that the Holy Spirit should renew the 
Church "as by a new Pentecost". Then, drawing from this interpretation of Vatican II and its reception, as well as from Louis-Marie Chauvet's distinction between "language as instrument" and "language as mediation", I analyze three examples of embodied prayer language frequently expressed by members of the Renewal: glossolalia, the raising of hands, and "resting in the Spirit". From this analysis I argue that the embodied prayer language of the Catholic Charismatic Renewal aligns best with a post-Vatican II theology of charism when it is interpreted as mediating what Chauvet refers to as divine "present absence" rather than as an instrument to move beyond human limitation to experience divine power directly. The approach of Chauvet's conception of divine "present absence" is to acknowledge the divine as fully present in embodied encounters without claiming that God is contained by or controlled within that same encounter.

In employing Chauvet's hermeneutic approach, I intend to offer a counter theological approach and remedy to metaphysically charged theological approaches that become mired in questions of causality. In doing so, I am making an original application of what is known as the "critique of onto-theology" to the Catholic Pentecostal experience. Other aspects of the Renewal outside the scope of this present study-such as the extensive debate regarding the Pentecostal phenomenon known as "baptism in the Spirit", which has been well summarized by Martin (2011) and Joy (2005)—could additionally benefit from the kind of analysis performed here.

\section{2. "As by a New Pentecost" as an Interpretive Hermeneutic}

On 25 December 1961, John XXIII convoked the Second Vatican Council with his apostolic constitution Humanae salutis, praying that God would show again the wonders of the newborn Church in Jerusalem "as by a new Pentecost" (John XXIII 1961, sct. 23). This prayer, as Thomas Hughson argues, has "interpretive potential" for the Council and its reception (Hughson 2008). It signifies a belief in the power and working of the Holy Spirit not just at the Church's inception, but also in the continued guidance of the Church by the Spirit. This belief in the Holy Spirit's continued guidance affirms that divine activity is needed not just to institute the Church but to continue its existence and renew it for every age moving towards its final completion. Hughson argues that while, for example, the "focus on the role of the Spirit in the formation of the church was a theologically significant step taken by Vatican II in Chapter 1 of Lumen gentium", employing "a new Pentecost" as a hermeneutic for the Council "does not primarily refer to teaching on the Spirit but to influence from the Spirit" (Hughson 2008, pp. 17, 21). John XXIII's plea for a "new Pentecost" is not, according to Hughson, a plea for a "a second Pentecost, a second founding of the church, a second commencing of the coming of God's kingdom" but rather "signifies that the temporal effect in the mission of the Spirit is still moving toward the eschaton, remaining always new and renewing" (Hughson 2008, p. 31).

Not six years following John XXIII's prayer and two years following the close of Vatican II, in 1967, a group of students at Duquesne University in the United States prayed while on retreat for an infusion of the Holy Spirit that they might also experience the power of Pentecost. In preparation for the retreat, the students were asked to read the first four chapters of Acts and David Wilkerson's The Cross and the Switchblade (Mangan 2008, p. 17; Mansfield 1992, p. 34; Wilkerson et al. [1963] 1977). At the start of each session, they sang the hymn Veni Creator Spiritus, "Come Creator Spirit" (Mangan 2008, p. 17; Mansfield 1992, p. 35). One retreat presenter spoke on Acts 1:8 echoing the words of Jesus that "you will receive power when the Holy Spirit comes upon you" and likened the Greek word for "power" (dynamis) to "dynamite" (Mangan 2008, pp. 17-18). Enflamed by the desire to have a dynamic relationship with the Spirit mirroring that of Pentecost, David Mangan, one of the students on retreat, reported to have experienced an awe-inspiring sense of the presence of God subsequently receiving the "gift of tongues", which is more formally known as "glossolalia" (Mangan 2008, p. 25). Other students on the same retreat followed soon after in receiving what they would also interpret to be gifts of the Spirit, or "charisms". Those emerging from this retreat shared their experiences with colleagues at 
the University of Notre Dame, who in turn sought similar experiences and shared their experiences even further (Ranaghan and Ranaghan 1969). Out of the spiritual experiences of the Duquesne retreat soon arose an international phenomenon known as the Catholic Charismatic Renewal.

John XXIII's prayer for a "new Pentecost" quickly became a self-interpretive anchor point for the Renewal. One witness from the "Duquesne Weekend", as the Duquesne retreat came to be called, described his encounter with the Spirit to his Notre Dame colleagues saying, "I do not have to believe in Pentecost, because I have experienced it" (Ranaghan and Ranaghan 1969, p. 42). In 1969, Kevin and Dorothy Ranaghan, who were among those witnessed to at Notre Dame and who in turn were touched by the power of the Spirit, published an account of the origins of the Renewal in the text Catholic Pentecostals that is prefaced by a quote of John XXIII's prayer for a "new Pentecost" drawn from Humanae salutis (Ranaghan and Ranaghan 1969). By 1973, the movement came to the attention of Léon Joseph Cardinal Suenens. Suenens, a moderator at the Second Vatican Council, had played a significant role at the Council in defending a theology recognizing the continued distribution of charisms among the faithful (Suenens 1975, p. 30). In 1974, Suenens published a work, which would later be translated into English as A New Pentecost?, that connected the work of the Holy Spirit in renewing charisms in the Church, particularly charisms as sought for and expressed by the Renewal, as a divine response to John XXIII's prayer for a new Pentecost (Suenens 1975, p. 77). In 1992, on the silver jubilee of the 1967 Duquesne retreat, one of the participants of that retreat, Patti Gallagher Mansfield, published her account of spiritual transformation from that retreat entitled As By a New Pentecost (Mansfield 1992). By 1997, Paul Josef Cordes, who was designated “Episcopal Adviser" to the Renewal following the resignation of that role by Suenens, also interpreted the Renewal as "one of the signs of [the] recovery of Pentecost as a permanent part of the Church's life" (Cordes 1997, p. 10).

While members of the Charismatic Renewal came to interpret their charismatic prayer experiences as a fulfillment of John XXIII's prayer for a "new Pentecost", a theology of charism has been slow to catch up. The matter of charisms came up in the council but was hotly contested and was ultimately addressed minimally in Council documents. During Vatican II, Suenens had contended that charisms are not only necessary to the Church but also that they continue to be given to the Church in the contemporary world. His interlocutor, Cardinal Ruffini, argued by contrast that the gifts of Pentecost were unique to the early church. It was Suenens' position that would win out at Vatican II, and Lumen gentium would proclaim that, in addition to the sacraments and ministries of the Church, the Holy Spirit "sanctifies", "leads", and "enriches in virtue" the People of God by "distribut[ing] special graces [i.e., charisms] among the faithful of every rank" so that "by these gifts he makes them fit and ready to undertake various tasks and offices for the renewal and building up of the Church" (Lumen Gentium 1964, sct. 12). Suenens was not only a force for progress on the theology of charisms during Vatican II, but also in the post-conciliar years. What little theological work has been done owes a significant debt to Suenens (Donnelly 1999). Nevertheless, while influenced significantly by Protestant Pentecostalism and supported marginally by Catholic theological reflection, the Renewal has sought to reinvigorate the Roman Catholic Church from within and is marked by fruits appropriate to a renewal of the Catholic Church such as a greater devotion to the sacraments and love for the scriptures (Sullivan 1982, pp. 56-57). As a testament to the Renewal's contributions to the revitalization of Church life, the Renewal caught the attention of and was supported in its early days by members of the ecclesial hierarchy such as Suenens, and later by papal authority. Thus, while a theology of charism has been challenging to develop, a praxis of charism has been alive and well within the Church.

\section{Embodied Spiritual Phenomena and Their Interpretation}

While the spiritual fruits of the Charismatic Renewal have become lauded and well recognized within the institutional church, embodied manifestations of those charisms 
have not fared as well. For example, in his work A Controversial Phenomenon: Resting in the Spirit, Suenens, an otherwise staunch supporter of what he prefers to call the "Pentecostal" movement within the Catholic Church, interrogates the phenomenon known as "resting in the Spirit" for its pastoral significance within the Renewal (Suenens 1987). What Suenens concludes is that bodily manifestations of the Spirit are so "ambiguous" in their provenance that attributing them to the working of the Spirit is dubious and, therefore, should not be pastorally encouraged (Suenens 1987). Though "resting in the Spirit" will be addressed in further detail below, what is significant at this point is to recognize the discomfort expressed by Suenens and others with embodied prayer forms. What Suenens specifically rejects in practice is interpreting these encounters as effected by the Holy Spirit, yet in rejecting this specific interpretation of the embodied event, Suenens comes to reject the entire event itself. Similarly, Vatican II peritus and theologian Yves Congar, in his milestone three-volume text on the Holy Spirit entitled I Believe in the Holy Spirit, cautions against an assumed "theology of immediacy" wherein the immediacy of divine presence is grasped through experience such that "Christians look for and find a response or a solution in a quick, immediate, and personal relationship that cuts out long and difficult approaches" (Congar [1979] 1997, pp. 165-66). Congar argues that, while he believes God does guide and intervene in creation, it is unclear whether the manifestations claimed by the Charismatic Renewal are indeed effected by the Holy Spirit or whether the events are merely psychical (Congar [1979] 1997, pp. 166-67).

What I suggest is that such bodily phenomena should not be rejected wholesale but reinterpreted. This I shall attempt using Chauvet's distinction between language as instrument and language as mediation. I suggest that interpretations such as Suenens' and Congar's are characterized by treating embodied prayer language instrumentally, that is, as analyzable in terms of cause and effect, rather than as a form of mediation, which sees the body as the locus where the most holy and the most quotidian meet.

In the category of language Chauvet places the totality of human expression, both verbal and non-verbal, which means that embodied prayer forms such as glossolalia, the raising of hands, and "resting in the Spirit" are fundamentally linguistic expressions (Chauvet 2001). "Language as instrument" and "language as mediation" are not two functions of language but two ways of interpreting the significance of language (Chauvet 2001). In short, when language is treated as an instrument, it problematically denies significance to human embodiment, whereas language when treated as mediation better respects human embodiment.

\subsection{Language as Instrument}

According to Chauvet, when one perceives language as being instrumental, one imagines language to be a tool to get at some reality behind language (Chauvet 2001). This model posits a kind of immediacy between subject and reality. The subject, according to this model, is an ideal reality that stands fundamentally outside of language. The subject, standing outside of language, uses language as a kind of bridge between itself and other realities. Chauvet argues that "it is granted [by those employing this model] that the frailty of human beings is such that this relation [between subject and reality] is always somehow blurred by errors of perception, of transmission, of reception", yet, "it is surmised [by those interpreting language as instrument] that, thanks to progress which each one can make and the amelioration of procedures, these errors [caused by language in the relationship of subject with reality] are corrigible, at least partly, in this world" (Chauvet 2001, p. 4).

The essential problem with this model, for Chauvet, is that the human subject becomes detached from contextuality and attempts to seize or grasp at some reality "behind" contextuality to avoid the messiness of contextualizing factors such as embodiment. That is, by employing this model, the human subject attempts to "evade the contingency of the sensible, bodily, social, historical mediations" (Chauvet 2001, p. 4). Chauvet argues that language was so instrumentalized by figures such as Augustine and Thomas Aquinas that it became thought of as a consequence of Original Sin, or a kind of "obstacle" to "self- 
realization and to the possession of truth", which, as Chauvet notes, is an odd position for a Christian for whom Christ is the "Word of God" (Chauvet 2001, pp. 5-6). Chauvet argues that the model of language as instrument is an expression of preferring what is eternal, permanent, and stable over what is in the process of becoming (Chauvet 2001, p. 5). The model of language as instrument rests on the unconscious presupposition that "sensible mediations are obstacles to truth" (Chauvet 2001, p. 6). For Chauvet, preferring the stable over the becoming is an expression of preferring "soul" over "body". It dichotomizes the human experience so as to make the soul preeminent while skipping over human embodiment.

When embodied prayer languages, such as glossolalia, the raising of hands, and "resting in the Spirit" are treated as instrument they are treated in a mechanistic fashion so as to relate the soul directly to God. This mechanistic treatment of embodied phenomena can be and is often interpreted in two ways: one wherein the direct relationship to God is interpreted to be established "magically" or one wherein the direct relationship is interpreted to be established through "divine action" or what might also be thought of as "divine intervention".

When the immediacy of divine presence is interpreted in a "magical" sense, one believes that the person experiencing the embodied phenomenon calls down or enables divine action such that divine action is consequent upon human action. This is such that, for example, the raising of hands is interpreted as bringing about divine blessing or enabling God to work in a person's life by removing the perceived obstacle of bodily or sensible interference with divine action. Along with this interpretation are assumptions that such embodied mediations as history and culture stand in the way of access to the divine. A second way embodied prayer becomes interpreted as instrument is through a "divine action" or "intervention" model wherein one believes that God directly acts upon the subject through physical mediation. It is this interpretive model of "resting in the Spirit" that Suenens is effectively rejecting when he rejects the phenomenon. According to the "divine action model" of resting in the Spirit, God is directly working on the soul and uses falling as means to affect that work.

Notice that in both the interpretation of embodied prayer as "magical", that is as a tool to effect or enable divine change, and/or as a tool through which God acts on the soul, these interpretations are privileging the question of causality and presume the body to be something to manipulate, whether by God or human persons. According to the "magical" interpretation, the body is perceived either as a means to cause divine action or as a hindrance to divine work that needs to be given up, such as when in the raising of hands or in "resting in the Spirit" the posture of the body is used to signal surrender from sensible attachments. According to the "divine action" or "intervention" interpretation, God directly causes the surrender of sensible mediations. Interpretations of prayer languages as instruments results in pressing the question "who causes what?" Is the person using the body to try to grasp or seize at the divine or is the divine using the body to grasp or seize the person? Either way one answers this interpretive question, there is a manner of violence being done to the individual because the person's fundamental embodiment is not accounted for.

\subsection{Language as Mediation}

In contrast to "language as instrument", Chauvet poses an interpretation of language as mediation. Chauvet argues that "while human beings existed before inventing instruments such as the hoe or the arrow, they did not exist before language (and consequently culture)" (Chauvet 2001, p. 7). A human subject pre-existing language is an impossibility, for Chauvet. Language and the subject are contemporaneous and build each other up in tandem.

For this interpretation of language, the phenomenon of language is fundamentally embodied. Chauvet calls the body "the place in which the most internal and external meet or the external place in which the internal finds its structure" (Chauvet 2001, p. 1). 
Language has history and culture and is subject to human contingencies. The body is not a mere tool to be guided towards some end or purpose of the soul, but an expression of the personhood of the subject. Language is an expression of the fundamental quality of the human person to be social, to be with others, whether those others are other humans, other non-human creatures, or even God.

According to this interpretation of the significance of language, language mediates between the subject and reality such that both "subject" and "reality" are constructed by language. This construction imparts meaning to experience and is a kind of lens through which a subject encounters reality. When I encounter a tree, I am interpreting the experience of encounter as "tree". Not only do I experience the encounter as "tree", but by experiencing it thus, I experience my significance as a subject with respect to the tree such as my responsibility as a member of human society to encourage plant life in the face of deforestation. The encounter with what I call "tree" is not a sensorium placed on the field of a tabula rasa but a lived encounter that has cultural and historical meaning and significance. The body is not a tool or vessel through which I encounter the tree but a means of being-together with the world of my experience, which includes that which I encounter as "tree". This "world of experience", inspired by, though not identical to Heidegger's being-in-the-world, does not make a sharp distinction between "spirit" and "matter" but emphasizes the fundamental contextualization in my encounter of the world. In the phenomenon of divine encounter, the divine is not somehow above or beyond the world but engaged through and in it.

Whereas language as instrument assumes a direct, immediate relationship between subject and object (e.g., between myself and the tree), language as mediation rejects this assumed relationship, by defending the contextualized, interpretive, and, thereby, embodied quality of the relationships among subjects and objects (e.g., my interpretation of the tree as "tree" and the resistance of the tree to my interpretation of it). Language as mediation, for Chauvet, leads to positing an account of divine "present absence". In encountering the tree, I am not directly encountering the tree in its full reality. In the fullness of its reality, the tree is absent to me. However, through embodied mediation, the tree is present to me as I am present to it. Likewise, God is absent to the worshipper in terms of the fullness of the divine reality, but God is present through the mediation of language.

What the interpretation of language as mediation looks like for embodied prayer is that embodied prayer forms should not be interpreted in terms of immediacy. The emphasis in this sort of interpretation is not one of causality, not a question of who causes what, but an emphasis on the being-togetherness, or sharing, of God and the Christian community. Chauvet describes this phenomenon with respect to the sacraments as "the Word of God at the mercy of the body" (Chauvet 2001). Thus, for example, the psychical quality of an experience is not grounds for dismissing a particular phenomenon in its divine encounter. For centuries, negative psychical qualities such as the experience of spiritual aridity have been interpreted as indicating an approach to divine encounter. Though this has been at least partially due to a distrust of embodied phenomena and potentially indicates an attempt to strip away embodiment, negative psychical qualities are still psychical qualities. "Spiritual aridity" is one way of interpreting a very real psychical experience as an encounter with God. The aridity itself mediates the divine in present absence. If this is the case, positive psychical qualities, such as the physical elation members of the Charismatic Renewal experience in praise and worship, should not be rejected as mediating divine presence simply because they are embodied. Nevertheless, positive psychical qualities are treated with suspicion because they could be interpreted as indicating divine immediacy, whereas it is, perhaps, assumed wrongly that negative psychical qualities lack this same danger. The problem is not the psychical encounter itself but the interpretation of embodied phenomena as instrumental.

By contrast, when embodied prayer languages, such as glossolalia, the raising of hands, and "resting in the Spirit" are treated as mediations they become the locus in which the person encounters God and the creaturely community. They express a kind 
of being-together in present absence. To examine this further, each of the phenomena of glossolalia, the raising of hands, and "resting in the Spirit" will be addressed in turn and analyzed according to the framework of language as mediation in contrast to language as instrument.

\section{Glossolalia, the Raising of Hands, and "Resting in the Spirit"}

\subsection{Glossolalia}

Sullivan, whose text Charisms and Charismatic Renewal: A Biblical and Theological Study works towards developing a Catholic theological treatment of the Charismatic Renewal in contrast to the more popular works that came before, describes glossolalia, which is more commonly known as the "gift of tongues" or simply "tongues", as an "unintelligible 'language'" in which persons can pray, speak, and sing that is often believed to be the same charismatic gift that St. Paul addresses in his First letter to the Corinthians (Sullivan 1982, p. 121).

Using William J. Samarin's study Tongues of Men and Angels, The Religious Language of Pentecostalism, Sullivan describes glossolalia as "human speech that sounds like real language, but when analyzed is found not to be real language" (Sullivan 1982, p. 132; Samarin 1972). While Sullivan argues that these are not nonsense syllables deliberately strung together to make a pseudo-language, he is also hesitant to call the phenomenon that is the "gift of tongues" language (Sullivan 1982, pp. 139-40).

Sullivan's definition of language is clearly narrower than Chauvet's, and, I suggest, indicates his discomfort with describing the phenomenon of glossolalia as language, properly speaking. It is the case that tongue languages are generally not expressions of known, widely spoken languages, and, on the rare occasion when this is the case, the phenomenon is referred to with a special term as xenolalia. Even in the circumstances of xenolalia, the language spoken is generally unintelligible to the speaker. This unintelligibility by speaker and listeners can often lead to criticisms that the tongue language spoken is a kind of "baby talk" or is an effusion of verbal nonsense. Samarin concludes that because glossolalia is neither (1) internally organized nor (2) "systematically related to the world man perceives", it is not language (Samarin 1972, pp. 127-28). Samarin's definition of language, noticeably, assumes language's utility. An expression is not language, for Samarin, unless it has the function of pointing to other realities in the experiential world. That is, Samarin subscribes to the interpretation of language as instrument. Sullivan, in some sense, attenuates this position by arguing that while tongue languages are not language in the "proper sense of the term", he would not "deny that glossolalic utterances can be, and often are, expressive of feeling and thought" (Sullivan 1982, p. 133). Nevertheless, Sullivan's attenuation still focuses on language's utility. Sullivan argues that the "value of [the gift of tongues] seems to lie in its freeing the depths of the human spirit to express audibly and vocally (that is, with the body as an integral part of the self) what it cannot find words to express in conceptual language" in order to "signify and intensify one's attitude of prayer" (Sullivan 1982, pp. 144, 145). Though Sullivan's position helps in attempting to redirect the focus of causality into a realm where embodiment matters, the significance of embodiment is still preeminent as a matter of causality. The "mind" is something to be side-stepped in order to prepare the "heart" to speak (Sullivan 1982, p. 144). According to this interpretation of language as instrument, praying in tongues takes on a kind of "magical" significance where the question becomes "what can I do to enable God to act in my life?" and the solution lies in the diminishment of human contextuality.

By contrast, when the gift of tongues is interpreted according to the paradigm of language as mediation, the relevance of causality fades away. The major question becomes not one of causality but one of being-together in present absence. When the "gift of tongues" is treated as mediation, the purpose is not to try to get at some divine being beyond contextuality but engaging with a phenomenon of being-with the divine. The opening of the mouth, the vocal expression of utterance, the community in which and with which one prays, all become phenomena of divine encounter. Tongues becomes 
not a means by which to prepare the self to encounter God, but that through which the human person encounters self, other creatures, and God. To speak or sing in tongues is a locus where humanity and divinity meet. This is a locus of "present absence" in the sense that God is both fully, contextually present within the phenomenon while also not being contained within or controlled by the phenomenon.

One consequence of interpreting the phenomenon of tongues as mediation addresses another concern voiced by both Suenens and Congar, which is the "risk of attributing charisms to a particular group, as though the whole body of believers were deprived of them" (Congar [1979] 1997, p. 162). This is the concern that if one need be a member of the Charismatic Renewal to participate in the gifts of the Spirit, it suggests that one must be a member of that movement in order to participate in the Body of Christ. As Congar argues, it would be a position that ignores that there are many forms of renewal occurring within the Church (Congar [1979] 1997, p. 163). However, this concern reflects another example of "magical" thinking by Suenens and Congar because it assumes that one designates the significance of praying in tongues or one of the many other charisms associated with the Charismatic Renewal as causally significant in approaching the divine. Interpreting the phenomenon of language as mediation rather than instrument, restores the gift of tongues as a contextualized expression. By interpreting praying in tongues as a matter of contextuality, circumstances could be otherwise. Praying in tongues becomes one locus of divine encounter, while leaving other potential contextualized loci free. The divine is mediated through all contextuality, so no one contextualization can claim to encompass the totality of the Body of Christ.

Returning to John XXIII's prayer for a renewal of the Church "as by a new Pentecost" as an interpretive hermeneutic for the Renewal, with respect to language as mediation, the focus is not so much on verifying whether the Renewal is an active manifestation of divine action in renewing the Church but on the encounter of the being-togetherness of the Word of God with the Church.

\subsection{The Raising of Hands}

While there is scant literature discussing and attesting to the practice of raising hands during charismatic prayer, this practice is indeed common and prevalent within charismatic circles. Fabio Giardini, in his theological and phenomenological investigation of Christian prayer, argues that because Christians "should pray with their whole being", their prayer should integrate both psychic and bodily factors such as "posture, particular gestures, especially of the hands and arms, facial expressions, words and songs, tears, sighs, groans, murmuring or shouts, etc." (Giardini 1995, pp. 153-54). The raising of hands is an interesting case because, while it is prominent almost to the point of being taken for granted within charismatic circles, it is not often thought of as a charism in the same way as praying in tongues. Perhaps because it tends to be seen in a more voluntary light, that is, as being under the control or causality of the worshipper, it is less associated with the grace of the Spirit. However, such a line of reasoning aligns more directly with language as instrument rather than as mediation due to its focus on who is causing what and when. One could argue more along these lines that while charisms are creaturely, they participate incarnationally in the Holy Spirit's work of effecting the communion that is the Church. Nevertheless, setting aside language as instrument and returning to language as mediation, the raising of hands, like prayer in tongues, is also an embodied prayer form that mediates divine encounter. It mediates the being-in-community, the togetherness, of the Body of Christ.

The raising of hands can mediate a variety of embodied contextualities such as praise/adoration, thanksgiving, penance, and petition. It is particularly an embodied manifestation symbolic of lifting up or surrendering one's whole being or selfhood to the divine. As addressed above, this can be problematic when the intent of the action is interpreted instrumentally as attempting to set aside embodiment to grasp at the divine directly. Rather, a more appropriate interpretation of such surrender might be a handing 
over of selfhood so as to encounter divine present absence in the fullness of the embodied phenomenon, the being-together-ness of God and all creation.

\section{3. "Resting in the Spirit"}

The phenomenon of "resting in the Spirit", which is also commonly known as being "slain in the Spirit", is often described as a kind of "overpowering" engagement with divine grace such that the worshipper physically falls down, more often than not, backwards (Suenens 1987). The phenomenon has been so common that prayer situations in which the falling tends to occur are often accompanied by persons who can catch a falling worshipper, or, as in the case of "praying over" a worshipper, the prayer can be conducted with the worshipper seated in order to minimize the impact of falling. In the act of falling, persons sometime experience a kind of "spiritual, emotional, and physical refreshment", but also sometimes "weakness or faintness" or "fear and confusion" (Suenens 1987, pp. 22-23). Fruits associated with this experience often include phenomena such as "alleviation" or "healing" of psychic disturbances or "inner wounds and resentments"; "healings of damaged relationships" such as marriages; "feelings of peace"; a greater depth of commitment to forgiveness, repentance, prayer, and/or scripture; a phenomenon of deep encounter with Jesus; and, though rarely, physical healings (Suenens 1987, p. 23).

This phenomenon particularly concerns Suenens because the physical act of falling can be and has been not unusually interpreted as having been caused or effected directly by the Holy Spirit. In contrast to the raising of hands and praying in tongues which tend to be interpreted in a more "magical" sense as a matter of human agency, "resting in the Spirit" is often interpreted more in the direction of "divine action" or "intervention". Though it is generally believed that a person can resist the phenomenon of "resting in the Spirit", the causality of the falling itself is often preponderantly placed on the Spirit (Suenens 1987, p. 21; Csordas 1997). Just as occurs with praying in tongues and the raising hands in prayer, this phenomenon is also often interpreted in light of language as instrument, as a matter of who causes what and how.

When the act of falling is interpreted according to language as mediation, the act of falling becomes a participation in the life of the Spirit in such a way that the Spirit is neither absent from nor contained by the encounter. In line with Suenens' argument, one can argue that the "overpowering" quality of the experience should not necessarily be interpreted as an action of the Spirit directly on the body, as this suggests that the decisionmaking capacities of the human person are being by-passed. Rather, the experience might more effectively be interpreted as a participation of the fullness of embodiment in divine encounter.

\section{Looking Forward}

Rather than approaching physical phenomena of prayer with suspicion out of fear of misattributing to them incorrect causality, physical phenomena should be evaluated according to their mediation of divine encounter. The fact that interpreting a prayer phenomenon could be led astray (e.g., as when causality for "resting in the Spirit" is misattributed incorrectly as divine or human action) is insufficient grounds for rejecting the physical phenomenon (e.g., the phenomenon of resting in the Spirit) itself, as such a rejection expresses an undue preference against embodiment. The alternative approach suggested here, emphasizing language as mediation rather than as instrument, does involve a hermeneutical stance potentially unfamiliar to the average charismatic Catholic and guiding cleric. In that the Renewal has been so consistently and successfully interpreted as one faith expression fulfilling John XXIII's prayer for renewal "as by a new Pentecost" suggests that the embodied prayer forms associated with the Renewal are significant to what a renewal in the Church must mean. That is, a renewal of the graces of Pentecost fundamentally involves reconnecting to the richness of that embodied encounter of the divine experienced by early Christians.

Funding: This research received no external funding. 
Acknowledgments: Thank you to the Franciscan University of Steubenville John Paul II Library for maintaining and allowing the use of their collection pertaining to the history and expression of the Catholic Charismatic Renewal.

Conflicts of Interest: The author declares no conflict of interest.

\section{References}

Bagiackas, Joseph. 1983. The Future Glory: The Charismatic Renewal and the Implementation of Vatican II. South Bend: Charismatic Renewal Services.

Chauvet, Louis-Marie. 2001. The Sacraments: The Word of God at the Mercy of the Body. Collegeville: The Liturgical Press.

Congar, Yves. 1997. I Believe in the Holy Spirit. New York: The Crossroad Publishing Company. First published 1979.

Cordes, Paul Josef. 1997. Call to Holiness: Reflections on the Catholic Charismatic Renewal. Collegeville: The Liturgical Press.

Csordas, Thomas J. 1997. The Sacred Self: A Cultural Phenomenology of Charismatic Healing. Berkeley: University of California Press.

Donnelly, Doris. 1999. Introduction. In Retrieving Charisms for the Twenty-First Century. Edited by Doris Donnelly. Collegeville: Liturgical Press.

Giardini, Fabio. 1995. Theological phenomenology of prayer. In Compendium of Spirituality. Edited by Emeterio De Cea. Translated by Jordan Aumann. Staten Island: Society of St. Paul, vol. 1, pp. 153-68.

Hughson, Thomas. 2008. Interpreting Vatican II: "A new Pentecost". Theological Studies 69: 3-37. [CrossRef]

John XXIII. 1961. Humanae Salutis. Available online: https://www.vatican.va/content/john-xxiii/la/apost_constitutions/1961 /documents/hf_j-xxiii_apc_19611225_humanae-salutis.html (accessed on 30 May 2021).

Joy, John. 2005. The outpouring of the Holy Spirit in the Catholic Charismatic Renewal: Theological interpretation of the experience. Antiphon 9: 141-65.

Lumen Gentium. 1964. Dogmatic Constitution on the Church. Solemnly Promulgated by His Holiness Pope Paul VI on November 21. Available online: https://www.vatican.va/archive/hist_councils/ii_vatican_council/documents/vat-ii_const_19641121 _lumen-gentium_en.html (accessed on 30 May 2021).

Mangan, David. 2008. God Loves You and There's Nothing You Can Do About It: Saying Yes to the Holy Spirit. Cincinnati: Servant Books.

Mansfield, Patti Gallagher. 1992. As By a New Pentecost: The Dramatic Beginning of the Catholic Charismatic Renewal. Steubenville: Franciscan University Press.

Martin, Ralph. 2011. A new Pentecost? Catholic theology and "Baptism in the Spirit". Logos 14: 17-43. [CrossRef]

Ranaghan, Kevin, and Dorothy Ranaghan. 1969. Catholic Pentecostals. Paramus: Paulist Press.

Samarin, William J. 1972. Tongues of Men and Angels, the Religious Language of Pentecostalism. New York: Macmillan.

Suenens, Léon Joseph. 1975. A New Pentecost? New York: Seabury Press.

Suenens, Léon Joseph. 1987. A Controversial Phenomenon: Resting in the Spirit. Dublin: Veritas Publications.

Sullivan, Francis A. 1982. Charisms and Charismatic Renewal: A Biblical and Theological Study. Dublin: Macmillan.

Synan, Vinson. 1997. The Holiness-Pentecostal Tradition: Charismatic Movements in the Twentieth Century, 2nd ed. Grand Rapids: Eerdmans.

Wilkerson, David, John Sherrill, and Elizabeth Sherrill. 1977. The Cross and the Switchblade. New York: Jove Books. First published 1963. 